\title{
Editorial: Memory T Cells in Chronic Infections and Tumors
}

\author{
Maike Hofmann ${ }^{1 \dagger}$, Camilla Jandus ${ }^{2,3 \dagger}$, Lian Ni Lee ${ }^{4 \dagger}$ and Daniel T. Utzschneider ${ }^{5 *}$ \\ ${ }^{1}$ Clinic of Internal Medicine II (Gastroenterology, Hepatology, Endocrinology and Infectious Diseases), Freiburg University \\ Medical Center, Faculty of Medicine, University of Freiburg, Freiburg, Germany, ${ }^{2}$ Department of Pathology and Immunology, \\ Faculty of Medicine, University of Geneva, Geneva, Switzerland, ${ }^{3}$ Ludwig Institute for Cancer Research, Lausanne, \\ Switzerland, ${ }^{4}$ Nuffield Department of Medicine and Translational Gastroenterology Unit, Peter Medawar Building, University \\ of Oxford, Oxford, United Kingdom, ${ }^{5}$ Department of Microbiology and Immunology, The Peter Doherty Institute for Infection \\ and Immunity, University of Melbourne, Melbourne, VIC, Australia
}

Keywords: exhaustion, memory T cells, chronic infection, tumor, PD-1

\section{Editorial on the Research Topic}

\section{Memory T Cells in Chronic Infections and Tumors}

Immunological memory by $\mathrm{T}$ cells is a fundamental characteristic of the adaptive immune system. The underlying principle is that exposure to a pathogen leads to the generation of long-lived memory $\mathrm{T}$ cells, which provide an immediate and stronger immune response following re-encounter of the same pathogen, ensuring effective protection following a pathogen reinfection or vaccination (1). While pathogenic eradication and thus re-establishment of quiescence has been assumed to be a prerequisite for the formation of immunological memory, recent advances in the field have revealed that $\mathrm{T}$ cells with memory-like characteristics can be found among exhausted

\section{OPEN ACCESS}

Edited and reviewed by: Scott N. Mueller,

The University of Melbourne, Australia

*Correspondence:

Daniel T. Utzschneider daniel.utzschneider@unimelb.edu.au

†These authors have contributed equally to this work

Specialty section:

This article was submitted to Immunological Memory, a section of the journal

Frontiers in Immunology

Received: 19 January 2021 Accepted: 01 February 2021 Published: 17 February 2021

Citation:

Hofmann M, Jandus C, Lee LN and Utzschneider DT (2021) Editorial: Memory T Cells in Chronic Infections and Tumors.

Front. Immunol. 12:656010. doi: 10.3389/fimmu.2021.656010 $\mathrm{T}$ cell responses in ongoing infections or in tumors (2). As such, these cells, distinguishable by the expression of the transcription factor T-cell factor 1 (TCF1) or the chemokine receptor CXCR5, retain proliferative potential and the ability to self-renew while also continuously replenishing the pool of antigen-specific exhausted effector $\mathrm{T}$ cells, thereby mediating viral or tumor control $(3,4)$. Interestingly, TCF1+ memory-like or precursor $\mathrm{T}$ cells can also exhibit features of $\mathrm{T}$ cell exhaustion, as described for many actively-persisting viral infections such as Human Immunodeficiency Virus (HIV) $(5,6)$ and Hepatitis B or C viruses in humans $(7,8)$, Lymphocytic choriomeningitis virus (LCMV) infections in mice $(3-5,9)$, and in tumor settings both in humans and mice (10-13). Most importantly, TCF1+ T cells are responsible for the boost of immunity following immune checkpoint blockade in immunotherapy $(3,4)$. Thus, promoting our understanding of the molecular characteristics of these memory-like or precursor T cells will drive the design and development of novel immunotherapies to modulate exhausted $\mathrm{T}$ cell responses in chronic infections and tumors.

This Research Topic was developed to encourage high-quality scientific outputs on this particular theme. As such, the Research Topic comprehensively highlights in two review articles as well as three primary research articles the importance of memory-like or precursor $\mathrm{T}$ cells in chronic infections and tumors. First, Martinez-Usatorre et al. unequivocally identified and established an improved cell sorting protocol to isolate TCF1+ precursor $\mathrm{T}$ cells from solid tumors. The authors performed transcriptomic analysis of PD1+ $\mathrm{T}$ cells derived from murine B16 tumors as well as primary human melanoma tumors to identify an enriched expression of Slamf6 by concomitant lack of Entpd1 (encodes CD39) and Havcr2 (encodes TIM3) expression among precursor $\mathrm{T}$ cells. Based on these expression patterns, they demonstrate that PD1+Slamf6+CD39-TIM3-tumor-infiltrating lymphocytes (TILs) displayed higher proliferative potential when isolated, transferred, and rechallenged, compared to the PD1+Slamf6-CD39+TIM3+ counterpart. 
Thus, Martinez-Usatorre et al. nicely demonstrate a viable approach to improve the isolation of superior TILs that can strongly advance efficacy of adoptive cell therapy.

Zhang et al. addressed the role of the inhibitory receptor CD160 on CD8 T cells responding to chronic viral infection. The authors first demonstrate that CD160 expression positively correlates with improved clinical signs such as enhanced CD4 T cell counts and reduced viral burden in people with HIV. Moreover, the authors utilize the preclinical chronic LCMV model to elegantly demonstrate that CD160 is required to maintain prolonged viral control. Importantly, the authors reveal that the lack of viral control is due to an impaired generation of TCF1+ precursor T cells in the absence of CD160 and thus an impairment in sustaining a long-term $\mathrm{T}$ cell response. Thus, signaling through CD160 is essential for the formation of TCF1+ precursor $\mathrm{T}$ cells in response to chronic viral infection.

Kumashie et al. set up a mouse model to study $\mathrm{T}$ cells responding to persistent antigen presented by hepatocytes. By doing so, the authors identify exhausted intrahepatic precursor $\mathrm{T}$ cells and demonstrate that these cells retain proliferate and self-renewal potential similar to splenic precursor $\mathrm{T}$ cells responding to chronic viral infections. Interestingly, the authors demonstrate for the first time that precursor $\mathrm{T}$ cells retain improved metabolic and mitochondrial potential compared to their CXCR5- counterpart. This is an important observation that addresses a central topic of how $\mathrm{T}$ cell exhaustion and

\section{REFERENCES}

1. Williams MA, Bevan MJ. Effector and memory CTL differentiation. Annu Rev Immunol. (2007) 25:171-92. doi: 10.1146/annurev.immunol.25.022106.141548

2. Kallies A, Zehn D, Utzschneider DT. Precursor exhausted T cells: key to successful immunotherapy? Nat Rev Immunol. (2020) 20:128-36. doi: 10.1038/s41577-019-0223-7

3. Utzschneider DT, Charmoy M, Chennupati V, Pousse L, Ferreira DP, Calderon-Copete $\mathrm{S}$, et al. T cell factor 1-expressing memory-like CD8(+) $\mathrm{T}$ cells sustain the immune response to chronic viral infections. Immunity. (2016) 45:415-27. doi: 10.1016/j.immuni.2016.07.021

4. Im SJ, Hashimoto M, Gerner MY, Lee J, Kissick HT, Burger MC, et al. Defining CD8+ T cells that provide the proliferative burst after PD-1 therapy. Nature. (2016) 537:417-21. doi: 10.1038/nature19330

5. Leong YA, Chen Y, Ong HS, Wu D, Man K, Deleage C, et al. CXCR5(+) follicular cytotoxic $\mathrm{T}$ cells control viral infection in B cell follicles. Nat Immunol. (2016) 17:1187-96. doi: 10.1038/ni.3543

6. Sekine T, Perez-Potti A, Nguyen S, Gorin JB, Wu VH, Gostick E, et al. TOX is expressed by exhausted and polyfunctional human effector memory CD8(+) T cells. Sci Immunol. (2020) 5: eaba7918. doi: 10.1126/sciimmunol.aba7918

7. Wieland D, Kemming J, Schuch A, Emmerich F, Knolle P, Neumann-Haefelin $\mathrm{C}$, et al. TCF1(+) hepatitis $\mathrm{C}$ virus-specific $\mathrm{CD} 8(+) \mathrm{T}$ cells are maintained after cessation of chronic antigen stimulation. Nat Commun. (2017) 8:15050. doi: $10.1038 /$ ncomms 15050

8. Hensel N, Gu Z, Sagar, Wieland D, Jechow K, Kemming J, et al. Memory-like HCV-specific $\mathrm{CD} 8(+) \mathrm{T}$ cells retain a molecular scar after cure of chronic HCV infection. Nat Immunol. (2021) 22:229-39. doi: 10.1038/s41590-020-00817-w

9. Utzschneider DT, Gabriel SS, Chisanga D, Gloury R, Gubser PM, Vasanthakumar A, et al. Early precursor T cells establish and propagate
T cell metabolism are regulated and connected. Li and Zhang dive into this field by reviewing the current literature of cellular metabolism of different memory $\mathrm{T}$ cell subsets and highlighting different possibilities to target mitochondrial metabolism to boost $\mathrm{T}$ cell memory formation and metabolic fitness to improve cancer immunotherapy.

Finally, the review by Nüssing et al. takes a step back and addresses specific similarities and discrepancies of $\mathrm{T}$ cell exhaustion and tolerance. The authors discuss how tumors can manipulate tolerance mechanisms to evade immune recognition.

Overall, this Research Topic contains a range of articles that highlight the critical role of memory-like or precursor $\mathrm{T}$ cells across a wide range of diseases emphasizing the importance to further improve our understanding of memory $\mathrm{T}$ cell biology to design new or improve the efficacy of current immunotherapies.

\section{AUTHOR CONTRIBUTIONS}

All authors contributed equally in writing the manuscript.

\section{FUNDING}

LN is funded by the Emerson Collective and Cancer Research UK (Biotherapeutics Drug Discovery Project Award A29991).

T cell exhaustion in chronic infection. Nat Immunol. (2020) 21:1256-66. doi: 10.1038/s41590-020-0760-z

10. Miller BC, Sen DR, Al Abosy R, Bi K, Virkud YV, LaFleur MW, et al Subsets of exhausted CD8(+) T cells differentially mediate tumor control and respond to checkpoint blockade. Nat Immunol. (2019) 20:326-36. doi: 10.1038/s41590-019-0312-6

11. Siddiqui I, Schaeuble K, Chennupati V, Fuertes Marraco SA, CalderonCopete S, Pais Ferreira D, et al. Intratumoral Tcf1 $(+)$ PD- $1(+) C D 8(+)$ T cells with stem-like properties promote tumor control in response to vaccination and checkpoint blockade immunotherapy. Immunity. (2019) 50:195-211.e10. doi: 10.1016/j.immuni.2018.12.021

12. Jansen CS, Prokhnevska N, Master VA, Sanda MG, Carlisle JW, Bilen $\mathrm{MA}$, et al. An intra-tumoral niche maintains and differentiates stemlike CD8 T cells. Nature. (2019) 576:465-70. doi: 10.1038/s41586-019-1 836-5

13. Brummelman J, Mazza EMC, Alvisi G, Colombo FS, Grilli A, Mikulak J, et al. High-dimensional single cell analysis identifies stem-like cytotoxic CD8(+) T cells infiltrating human tumors. J Exp Med. (2018) 215:2520-35. doi: $10.1084 /$ jem. 20180684

Conflict of Interest: The authors declare that the research was conducted in the absence of any commercial or financial relationships that could be construed as a potential conflict of interest.

Copyright $\odot 2021$ Hofmann, Jandus, Lee and Utzschneider. This is an open-access article distributed under the terms of the Creative Commons Attribution License (CC $B Y)$. The use, distribution or reproduction in other forums is permitted, provided the original author(s) and the copyright owner(s) are credited and that the original publication in this journal is cited, in accordance with accepted academic practice. No use, distribution or reproduction is permitted which does not comply with these terms. 